\title{
Not Very Poor, Powerless or Pregnant: The African Woman Forgotten by Development
}

\section{Everjoice J. Win}

\section{The appeal of the myth of the poor and powerless African woman}

For decades now, the development industry has thrived on the stereotypical image of an African woman who is its "target" or "beneficiary". Always poor, powerless and invariably pregnant, burdened with lots of children, or carrying one load or another on her back or her head, this is a favourite image, one which we have come to associate with development. From the United Nations, to large international agencies, to multilateral/bilateral donors, to small non-governmental organisations (NGOs), most of us have used and abused this image time and time again. Like the fly-infested and emaciated black child that is so often used by international news agencies, the bare-footed African woman Sells. Without her uttering a word, this poor woman pulls in financial resources. Any researcher worth their salt has to go to the "most remote" village to find her for their statistics on issues like access to water, to be valid. Similarly, the gender programme officer in any institution has to always demonstrate that her work is about the very poor and marginalised woman, for her to be regarded as legitimate.

But is this image an accurate one? Does it tell the full story of black African women's complex realities? And does this image encompass all levels of "marginalisation" and "disempowerment" that development work must deal with? In this new era of rights-based approaches, is this the only woman that development organisations should be concerned about? Is resource poverty the only lens through which we should look at women's rights denial and violations? As one of those women often forced to negate my own needs and experiences in the work that I do, I seek to challenge this image and consequent focus.

\section{HIV/AIDS: the new lens}

If there is one good thing to say about HIV/AIDS it is the fact that it has finally enabled feminists like me to articulate more clearly all the issues that I have often raised which did not seem to make sense to others. And it is by focusing on an issue that I have personally experienced as a middle class woman that I am able to adequately demonstrate my frustration with the way the development industry constantly delegitimises my voice and denies me a space. I will therefore use this example in exploding the myth of the poor, powerless and pregnant African woman.

It is now a well-established fact that gender inequalities are driving the HIV/AIDS pandemic. Women's inability to protect themselves and exercise choices, sexual violence and the lower status accorded to women and girls are some of the many aspects of women's greater vulnerability to HIV. Research has clearly shown that it is also women who bear the disproportionate burden of care for the sick, and yet suffer a lack of access to treatment for themselves. All of these facts apply not just to resource-poor women in remote rural areas, they apply to all women regardless of all the variables that we know - class, location, age, etc. The defining factor is unequal power relations between women and men. While resource poverty is an important factor, mediating the differences among classes of women, it is still a fact that generally most women experience unequal power relations regardless of class.

As a middle class woman, I am intimately affected by HIV/AIDS. I find it as hard to negotiate safe sex as any other woman. I have the same fears about the consequences of my actions as any other woman. I am afraid of what society thinks of me, I am afraid of what my family will say, I do not want to be constantly seen as a bad woman. Sexual violence stalks me wherever I go. Even when I travel 


\section{Notice: For the Development Bulletin Board}

\section{Attention: Researchers, Donors, Policy-makers, Northern feminists, Southern practitioners and other such-like}

\section{Sighted: "New" African woman - not very poor, powerless or pregnant}

A new African woman has recently appeared on the margins of the development stage. From reports received, this woman does not fit the usual stereotype that many of us have become used to in our work. Please find below a rough description of this new woman. You are all advised to urgently start looking out for her and to find ways of engaging and working with her. Please be warned that this woman is rather more complex than the old one we have come to know, who we see as much more simple and straightforward. You are therefore advised to exercise the greatest of caution when you approach her and spend a bit more time understanding her.

\section{Geographic location}

This woman can be found in many countries of Africa, particularly the sub-Saharan region. At the local level, she can be found in rural villages or in the urban areas. She moves between the two locations with ease. It is difficult to specifically say if she is fully a resident of one of the two. Her work spans the two as well. Some of her work is directly in her own village, while some is in the urban area where she also lives. Lately she has been elected as a representative in her local government.

It is at national level, though, that she is most active and she also appears at the regional and international level. You are likely to see her presenting a keynote speech at a regional donor conference, or running round the lobbies of powerful international institutions lobbying policymakers on the issues she is passionate about. The following week you will meet her again in the villages of her country, facilitating workshops, or organising economic activities with resourcepoor women.

\section{Class and other social characteristics}

The new woman is mostly middle to upper middle class - such as there is in sub-Saharan Africa. She is not very poor, nor can she be called very rich. Although she is relatively comfortable, in comparison to the majority of women in her communities, the new woman's comforts tend to be wiped out by the reality of her existence. For example, she is the one most likely shouldering the burden of HIV/AIDS; paying fees for orphans; buying anti-retrovirals for the infected and generally stepping in when governments and others fail.

to what some would see as exciting places - out of my country, to conferences - I worry about my safety and security in hotel rooms. I personally do not sleep in any hotel room without pushing a chair against the door, just in case!

My class has not been spared from the reality of HIV/AIDS. We are both infected and affected. Of course there are no class-disaggregated statistics. Stigma still knows no boundaries. I constantly get pointed out as 'the one whose mother has lost three children to AIDS!' The burden of care and support for the affected and infected falls on the shoulders of the middle class woman. She is the one with access to money, so she pays fees for the orphan here, takes the dying relative to hospital the next day, and generally the whole clan looks to her to pay for everything that is needed. She even sponsors the funerals. If she is married she has to do this for her own family and for His family.

The bottom line, when it comes to a problem like HIV/AIDS, or violence against women is I AM THE WOMAN. The issues I talk about are issues that I live with and experience. I am the one who mops up after everyone and on behalf of the state. I am the marginalised and oppressed. I am not working "for" the woman out there, who is nameless or faceless. This is about me. I do not have to ratchet up "grassroots women" to speak on behalf of, because I am that woman and I speak on my own behalf.

The big difference between development's favourite woman and me lies merely in the degree to which we each experience these problems. As they say, money 
does not buy happiness but it helps. Equally education, geographic location and access to resources do not buy gender equality - but they help. It is important to note, though, that I am constantly hovering on the brink of becoming the poor woman in the posters because of something like HIV/AIDS or violence. Many of us have been reduced to a handto-mouth existence by the demands placed on us by those around us. Because we are still subjected to practices like property grabbing, there is the everpresent possibility of finding oneself as destitute as the mythical development target.

\section{Silencing of the middle class woman}

Despite all of this, the middle class woman is completely silenced and erased from the images of development and rights work. She is constantly reminded that development is about eradicating poverty and therefore it focuses on those defined as "the poor" (read as resource-poor). Therefore her story and her experiences are not part of the narrative. In essence, this means women's lives are put on a kind of league table and it is those that qualify which get addressed.

If the non-poor woman dares give herself as an example, she is reminded that she is too distant from the lives of the women out there to matter. If she works in development, she constantly has to demonstrate how she is connected to the women at grassroots level. It is not acceptable to claim any knowledge of the issue(s) at hand. Many a women's organisation and its leadership have had to provide physical evidence of links with the grassroots poor. This can even go to ridiculous lengths, for example women's rights NGOs have been forced to take "their grassroots poor" to a UN meeting or international conference, just to prove their legitimacy.

The most disturbing aspect of all this is that none of these requirements are put on Northern feminists or other rights organisations. It is quite acceptable for a Northern academic feminist to present her paper in Beijing, or for her activist colleague to lobby the UN on HIV/AIDS. The world does not yet know how to deal with the articulate non-poor African feminist. Is it because she talks back? Is it because she does not fit the image of the charity case? As African feminists we have learnt to laugh at the comment made by our Northern colleagues: 'Oh you are 5000 articulate Everjoice!' We ask ourselves, what we were supposed to be? Incoherent?

\section{The dual identity}

Because for many years the work of the African middle class activist has had to focus on and be based in rural poor areas, she has one foot at the micro level and the other in macro spaces. This dual identity can only result in schizophrenia! It becomes extremely difficult to hone one's skills and expertise.

"Villagisation" of non-poor activists has resulted in the often-heard refrain, 'Africa has no policy analysis capacity'. The results are all too visible; it is still largely Northern academics or feminists who write and get published; it is their work, which is used by policy-makers and is quoted in international media. The "village-based" micro analyst, or anecdote-telling African activist is not that well respected. Her work often gets relegated to the human-interest stories section. At international conferences, it is the conceptual papers that get discussed, rather than the practical experiences or suggestions. Any academic journal will show the power imbalances between Northern and African feminists. Hardly does one find an article written by the ones on the front line.

The most recent fashion is co-authored articles, by Northern and African "writers", but one can still pick out who contributed what to the piece. Donors are equally reluctant to support work by African women that is not practical and grassroots oriented. Hardly do donors support feminist academics on the continent - strategic thinking processes, or macro policy work (including advocacy). But they have no problem giving resources to an Institute of Development Studies, or a Women's Studies Centre at a Northern University. Clearly the Northern colleagues definitely do not get asked in what way their work is going to directly impact on the lives of poor African women? Neither would they be asked to involve the grassroots.

How are African feminists and activists expected to strengthen or develop their intellectual capacities when we they are too busy running small projects, while others have all the space, the resources and the support they need?

\section{The personal is no longer political}

A more worrying offshoot of all this is that many African feminist activists find it difficult to live out the principle: the personal is political. By articulating issues that affect the other, the non-poor woman distances herself from even those struggles that should 
be hers. In the process she loses the ability to position herself within the solutions that she ultimately "prescribes" for others. So for example, on HIV/AIDS she will spread prevention messages that she herself has not even tried, or worse, knows do not work.

In the end she cannot really win, can she? On the one hand, she is seen as illegitimate if she does not dredge up the grassroots, and on the other, she cannot get close enough to the same grassroots, because she does not identify with their reality. It would enrich development work were non-poor women accorded the right and the space to tell their own story and work on issues that concern them. There would even be resonance and solidarity with Northern women who also have made telling the stories of others into an art form. Just like us, they suffer from violence, have the same concerns on HIV/AIDS, and on reproductive rights, etc. - even if there might be a difference in degree and other nuances. But the principal villain we are dealing with is the same - patriarchy and power relations. It would also enrich all women's lives were they to share stories, strategies and create solidarity platforms. But this can only happen if both sides come to this common space with honesty and without "othering" the other.

\section{Conclusion: creating new images and using new approaches}

The development community's new fad is the rightsbased approach. Perhaps this might offer a way for us to finally begin to move away from some of these stereotypes and myths about the African woman. The rights-based approach creates new opportunities for reconceptualising our understandings of poverty, for example. As various authors have shown, poverty is not simply resource poverty but includes violence, denial of personhood, silencing, marginalisation, denial of choice and other freedoms. All of these are experienced by the so-called "poor and other women".

Therefore, in rights-based approaches, resource poverty ceases to be "the" central distinguishing factor. Rather what matters is the denial and/or violation(s) of rights, which is based on nothing other than sex and gender. This, however, is not to suggest that all women are the same and that all women regardless of class, race and other factors should be treated the same. Development agencies can still choose among the various categories of women who they want to focus on and work with.
What I am suggesting is that there is need for conceptual clarity and a strategic shift from conceptualising poverty in very simplistic terms, and consequently choosing partners also based on these very simplistic understandings of the complexity of African women's lives. This shift would also enable development practitioners and donors in particular to move away from the simplistic "magic bullet" solutions that they often see for African women, examples of which include income-generating activities and awareness-raising campaigns. Just by looking at non-resource poor women, who do not need income-generating activities, and yet suffer from domestic violence or are infected with HIV/AIDS, would serve to answer the question: so, what else needs to change?

This strategic shift would see us moving beyond our favourite African woman, to strategic engagements with those other women who not only need support, but who can be strategic allies and leaders in development. But of course this means the power relations between Northerners and African women also shift dramatically. From seeing us as objects of charity - which those of us who are not poor, powerless and not likely to get pregnant are not - to seeing us as agents of our own change, from seeing us as junior partners with the anecdotes, to seeing us as analysts and macro level actors in our own right. And when we talk back and challenge, we would perhaps no longer be labelled "so difficult to work with" or "too sensitive".

Rights-based approaches give those of us who are not resource-poor a space within development discourse and practice to fully participate in change processes. This would help to re-energise us, as we become more emotionally and spiritually invested and uplifted by the work that we do. Because as long as we feel that "development" is about "others" far removed from our own realities, we will not see what we do as more than a job that we get paid for. Personal investment gives us the tools to live out the personal as political.

Most importantly, the strategic shift to rightsbased approaches would mean that we develop the courage to tell the good African stories, and show the positive images of African women. This might even begin to suggest redundancy for the missionaries among us. And then, hopefully, we can support the poor, powerless and pregnant one to deliver her babies and take a well-deserved rest. 